\title{
1. Price support schemes in the service of the EU's low-carbon energy transition
}

\section{Theodoros Iliopoulos*}

\section{INTRODUCTION}

The need for a low-carbon transition has been repeatedly emphasised by the European Union institutions and has been recognised as a long-term supranational strategy. ${ }^{1}$ And, of course, energy policy plays a key role in the attainment of this target. Accordingly, in 2015 the EU adopted the Clean Energy Package and in 2018 and 2019 enacted eight legal acts that put flesh on the bones of the Union energy strategy. Amongst these legal acts, one could highlight the new Renewable Energy Directive 2018/2001, also known as 'RED II'. ${ }^{2}$ This Directive establishes a legal framework for the promotion of energy from low-carbon renewable sources, which can replace fossil fuels and, thus, contribute to the reduction of emissions and to the mitigation of climate change.

RED II sets a target of at least 32 per cent share of energy from renewable sources in the Union's gross final consumption by 2030. This is a binding target for the Union as a whole; ${ }^{3}$ unlike the model that was in force under the previous Directive 2009/28, ${ }^{4}$ the collective Union target is not translated into mandatory national targets, but Member States decide on their own about the level of their national contribution to it. Yet, the discretion of Member States is not absolute. First, the share of renewable energy sources in the gross consumption of each Member State shall not drop below the 2020 national target, as determined by Directive 2009/28.5 Moreover, RED II explicitly refers to the Energy Union Governance Regulation, which is also part of the Clean Energy Package and confers on the Commission significant monitoring and intervening powers. According to the Regulation, the Commission assesses the level of ambition and the progress of Member States. If the planned contributions, policy objectives and measures are estimated not to be appropriate for meeting the collective target, the Commission issues 
recommendations, proposes measures and exercises its powers at Union level. ${ }^{6}$

In order to promote renewable energy sources and to comply with the foregoing rules, Member States mostly turn to certain economic policy instruments, namely support schemes for renewable energy sources (hereinafter 'RESSS'). Article 2(5) of RED II defines this concept as comprising:

any instrument, scheme or mechanism applied by a Member State, or a group of Member States, that promotes the use of energy from renewable sources by reducing the cost of that energy, increasing the price at which it can be sold, or increasing, by means of a renewable energy obligation or otherwise, the volume of such energy purchased, including but not restricted to, investment aid, tax exemptions or reductions, tax refunds, renewable energy obligation support schemes including those using green certificates, and direct price support schemes including feed-in tariffs and sliding or fixed premium payments.

Accordingly, RED II adopts a broad definition and provides an indicative list of RESSS. The next part provides a taxonomy of different RESSS and calls attention to the category of price support schemes.

\section{PRICE AND QUANTITY SUPPORT SCHEMES}

RESSS are either 'investment-focused', in the sense that they facilitate access to investment capital and grant support before the realisation of a project, or 'generation-based', meaning that they assist with the operation of a project over the years, and hence the support granted follows the actual generation of energy. ${ }^{7}$ Although there are important investmentfocused RESSS, like soft loans, subsidies, tax exemptions or tax credits for renewable energy installations, ${ }^{8}$ this contribution concentrates upon generation-based RESSS. This is because these are the main RESSS that Member States have employed, while investment-focused RESSS normally have a complementary role. For this reason, literature often refers to generation-based RESSS as primary RESSS and to investment-focused RESSS as secondary RESSS. ${ }^{9}$ Moreover, as will be demonstrated below, with RED II the Union legislator has shown a special interest in setting rules on the design of generation-based support schemes.

The generation-based RESSS can be further classified into quantity and price instruments. ${ }^{10}$ Under price RESSS, authorities set a price for energy from renewable sources and the market responds by adapting generation accordingly. This category typically includes feed-in tariffs and feed-in premiums. Feed-in tariffs are long-term contracts that oblige the grid 
operators to purchase the energy produced at a guaranteed fixed price. Feed-in premiums are similar to feed-in tariffs, but they only guarantee investors an add-on fee on top of the market price. Feed-in premiums often are not accompanied by a purchase guarantee, which means that producers still bear the burden to sell the energy they produce at the market. Last, the price RESSS group also comprises net metering. In net metering schemes, consumers produce the energy they consume on their own and they can sell any excess to the grid. ${ }^{11}$

On the other hand, under quantity instruments authorities require that a minimum amount of energy from renewable sources is generated. The price is then determined by the market and it is expected to rise, given that demand is increased due to the minimum quantity regulation. The exemplary instrument in this category is quotas and green certificates. In such systems, energy suppliers are required to supply to their customers a certain amount of energy from renewable sources. The compliance with the law is proven with tradeable green certificates, which become an independent commodity and ensure an extra source of revenue for producers. There is one more important quantity RESSS, namely auctions. Here authorities award a contract for the generation of a certain quantity of energy, often in a specific region or from a certain technology. Potential investors tender for the contract and the competition between them is expected to result in a price decrease. ${ }^{12}$

The following part examines the RESSS design choices that Member States have made so far and the stance that the Commission has adopted on these choices. This analysis will also reveal the distinctive features and the pros and cons of the two categories of generation-based RESSS.

\section{A REVIEW OF THE SUPPORT SCHEMES IN THE EUROPEAN UNION}

Over the years, Member States have showed their preference for price support schemes, especially feed-in tariffs and feed-in premiums. ${ }^{13}$ Accordingly, feed-in tariffs have been the main instrument employed, especially from the mid-1990s to the early 2010s, when most renewable technologies were still less mature and particularly costly, and a strong impetus was necessary for their development. Feed-in tariffs were considered capable of providing this impetus, as they offer a fixed price for each kilowatt-hour generated and a long-term purchase guarantee. These features ensure a certain stream of revenue for a long period and an investment environment with low risk. In addition, feed-in tariffs, as well as price RESSS in general, have the virtue of simplicity. The addressees 
just need to generate energy from renewable sources, without being burdened with participation in complex procedures or with other requirements. Simplicity is important for all investors, but especially for smaller investors and households who are not eager to or cannot afford to get acquainted with burdensome procedures that RESSS might entail. Given the above, price RESSS encourage investments and boost involvement in renewable energy projects. ${ }^{14}$

And indeed, the enactment of feed-in tariffs enticed significant investments in renewable energy projects. Czechia, Germany, Greece, Italy, Portugal, Spain and other Member States showed a high degree of ambition and attracted numerous investors who expected to reap significant risk-free profits. But the generosity of the RESSS enacted led to overinvestment and to overproduction of energy, which caused several problems and revealed the disadvantages that accompany price RESSS, especially feed-in tariffs. Accordingly, schemes with fixed prices do not react to market signals and market fluctuations; hence, while the sharp increase in energy supply would normally make prices drop in the EU, feed-in tariffs remained stable and beneficiaries kept on receiving the guaranteed price. Power ended up too costly and the beneficiaries were enjoying windfall profits. Such a market distortion entailed a significant burden for consumers, to whom the cost of financing feed-in tariffs was passed on. In general, price RESSS are usually financed by energy surcharges or energy levies imposed on consumers by the national authorities. In this sense, price RESSS resemble taxes, which makes them less appealing to those bearing the cost. ${ }^{15}$

In the end, feed-in tariffs could not be afforded and Member States imposed unilateral and abrupt changes to the regulatory framework, in an effort to make their RESSS fit the new market conditions. ${ }^{16}$ Exemplary is the regulatory failure of Spain, a leader in the development of renewable energy sources, and of Greece. In the early 2010s, recession exacerbated the inherent problems of the feed-in tariffs, as decreased power demand was added to the overproduction of energy. Spain and Greece saw their support regimes collapse and they resorted to a reduction of the feed-in tariffs granted. ${ }^{17}$ In another example, Germany also faced similar challenges and in the early 2010 s had to impose cutbacks in the tariffs too. ${ }^{18}$

Nevertheless, most Member States did not abandon price RESSS, but they turned to feed-in premiums. ${ }^{19}$ Feed-in premiums are more marketbased than feed-in tariffs, as the beneficiaries do not receive a permanently stable tariff, but a premium on top of the market price at which energy is sold. Since the remuneration granted depends on the actual market price, the risk that generators earn windfall profits and consumers pay too much for energy is reduced. Besides, it is not necessary that feed-in premiums 
are accompanied by a purchase guarantee; the beneficiaries might bear the burden to sell electricity at the market on their own. This reduces the risk of overproduction that would lead to overcompensation. ${ }^{20}$ Therefore, feed-in premiums are not as lucrative for investors; still, they are an important instrument for renewable energy policy. They constitute a simple, accessible and reasonable support scheme and they ensure investment security to a certain extent, as the beneficiaries receive a premium.

Opposite to the Member States' preference for price RESSS, the Commission has been always in favour of quantity RESSS, and especially quotas and tradeable green certificates. ${ }^{21}$ This stance argues that quantity support schemes in general better reflect the market conditions, they contribute to attaining the regulatory objective with the least distortion of the energy market and they engender a more stable regulatory framework. Under quantity RESSS, the authorities set down a target and it is then up to the producers to reach it with the least cost and to be adjusting to market changes, like the introduction of a new technology, fluctuations in supply and demand, inflation etc. And as the price is not administratively set, but determined by the market, it is expected that producers will not benefit from excessive profits. Besides, quantity RESSS are necessarily accompanied by procedural rules and compliance requirements, which allows authorities to monitor how the system works and also creates more fertile ground for communication between authorities and investors. ${ }^{22}$ Nevertheless, such conditions render quantity RESSS more complex, which might discourage involvement in them, while the fact that the level of remuneration is dependent on market conditions and that the producers are exposed to risk might spark less investment interest.

It should be also noted that green certificates can be easily designed to be traded beyond national borders, which is in harmony with the law of the free movement of goods. While price RESSS create a different situation in every Member State and thus aggravate the fragmentation of the European energy market, a quotas and certificates system can be a factor of market integration, which is an important supranational policy objective. ${ }^{23}$ However, in 2014, in the Alands Vindkraft case the Court of Justice of the EU (hereinafter 'CJEU') held that Member States might legitimately enact 'closed' RESSS that only apply to producers active within their borders on grounds of environmental protection. ${ }^{24}$ Thus, Sweden did not infringe the law of the free movement of goods by denying the award of certificates to a wind park located in Finland that sought to be covered by the Swedish RESSS. The judgment showed that without an explicit and clear obligation, Member States may limit the applicability of their RESSS to indigenous energy production, which is the common practice.

In view of the above, already since the mid-1990s the Commission has 
put forward a harmonisation plan that would determine one quantity RESSS as applicable in all Member States, and under the same terms. ${ }^{25}$ Nevertheless, Member States have proven unwilling to cede the power to determine the type of RESSS they use and have retained a wide discretion in the field. National discretion has been only restricted by a couple of soft law documents that ask Member States to opt for quantity instruments or feed-in premiums combined with auctions. ${ }^{26}$ In addition, the Commission has tried to exercise a certain control on the price RESSS on the basis of State aid law. In accordance with Article 107 of the Treaty on the Functioning of the EU, ${ }^{27}$ the Commission has exclusive competence to assess the legality of a selective aid granted from State resources. Accordingly, the Commission has repeatedly argued that price RESSS are indeed financed from State resources because the costs they entail are levied on the final consumers in a manner equating to taxation. The CJEU has been asked several times to answer if national price RESSS constitute State aid or not; but its case law is not consistent. In certain cases, the national price RESSS were found to be financed from State resources, while in other cases the opposite conclusion was reached and State aid law did not apply, which meant Member States did not have to comply with its requirements. ${ }^{28}$

The enactment of RED II marked the introduction of RESSS-specific provisions that further impact on the discretion of Member States. The following part analyses these provisions and the position of price RESSS within the new legal framework, which adopts a rather pro-quantity RESSS stance.

\section{PRICE SUPPORT SCHEMES UNDER DIRECTIVE 2018/2001}

While RED II contains several articles dealing with RESSS, the key provisions that relate to their type are found in Article 4. ${ }^{29}$ This article acknowledges the importance of RESSS and guides Member States to select the least market-distorting ones when it comes to the promotion of renewable sources for electricity. It does not provide that Member States shall opt for a certain RESSS, but it sets down the principles that any RESSS for electricity shall conform with. ${ }^{30}$ More specifically, Article 4(2) states:

[s]upport schemes for electricity from renewable sources shall provide incentives for the integration of electricity from renewable sources in the electricity market in a market-based and market-responsive way, while avoiding unnecessary distortions of electricity markets as well as taking into account possible system integration costs and grid stability. 
Consequently, RESSS for electricity are compatible with RED II as long as they are market-based and market-responsive and do not unnecessarily distort the market. Nevertheless, no definition of these concepts is provided.

Regarding the principle of 'avoiding unnecessary distortions of electricity markets', certain conclusions can be drawn from a systematic interpretation, by analogy with State aid law, which often examines whether a measure introduces an unnecessary distortion of competition or trade. ${ }^{31}$ Accordingly, the principle of proportionality and the performance of a balancing test are relevant here. Thus, RESSS that distort the electricity market can still be compatible with RED II if they are capable of and necessary for delivering the promotion of one or more renewable energy sources, without causing a disproportionately distorting effect. This non-unnecessary-distortions requirement does not give preference to quantity RESSS over price ones: price RESSS that only grant a reasonable premium might not have a distorting effect, while a poorly designed quantity instrument can be expected to cause an unnecessary distortion of the market. This was, for example, the case with the Flemish quotas RESSS, which resulted in a regulatory failure. The green certificates supplied by the Flemish authorities were so many that they outnumbered the demand and the certificates' recipients could not find enough buyers for all of them. In response, and with the aim to not halt the generation of energy from renewable sources, the authorities imposed a purchase obligation on the distribution system operators. Thus, the distribution system operators were required to purchase the green certificates that could not be sold at the market. The extra costs entailed would be borne by the Flemish Regulator for Electricity and Gas Markets and to that end a special tax was enacted; but the tax was annulled by the Constitutional Court of Belgium. ${ }^{32}$

Turning to the principles of market-based and market-responsive RESSS for electricity, the interpretative confusion is softened by RED II itself, as the first subparagraph of Article 4(3) elaborates on their content:

[s]upport schemes for electricity from renewable sources shall be designed so as to maximise the integration of electricity from renewable sources in the electricity market and to ensure that renewable energy producers are responding to market price signals and maximise their market revenues.

Consequently, RESSS are market-based if they are capable of delivering the integration of energy from renewable sources in the market to a greatest possible extent; and they are market-responsive as long as they incentivise producers to respond to market price signals, by ensuring that they will maximise their profits if they do so. 
The question raised at this point is whether price instruments for electricity can be in accordance with the principles of the market-based and market-responsive character of RESSS.

The answer is partly given by Article 4. Its paragraph 3 provides that 'with regard to direct price support schemes, support shall be granted in the form of a market premium, which could be, inter alia, sliding or fixed'. This shows that the Union legislator only considers feed-in premiums, and no other price RESSS, compatible with the foregoing principles. Nevertheless, Article 4(3) also adds that 'Member States may exempt small-scale installations and demonstration projects from this paragraph, without prejudice to the applicable Union law on the internal market for electricity'. Since Article 4(3) elaborates on principles set down by Article 4(2), a teleological expansion should apply so that the exemption also covers Article 4(2), as far as it concerns the principles of the market-based and market-responsive nature of RESSS. Differently, the introduction of the exemption would be meaningless; what would be exceptionally allowed under Article 4(3) would end up not complying with Article 4(2).

Consequently, price RESSS like feed-in tariffs, albeit non-market-based and non-market-responsive, can be compatible with EU law, as long as they only apply to small-scale installations that need specific conditions to be viable and to demonstration projects that also need special support to evolve. As for the definition of 'small-scale installation', RED II refers to State aid law. ${ }^{33}$ No definition of 'demonstration project' is provided.

At the same time, RED II makes no special reference to compatibility criteria for any quantity RESSS. This shows that no quantity instrument is regarded as de facto non-market-based and non-market-responsive. Member States can opt for any quantity instrument they deem appropriate, as long as it is in accordance with the general principles set down by Article 4(2) and (3). This legislative choice can be interpreted as a noticeable nudge for Member States to resort to quantity RESSS.

This conclusion is strengthened by the next paragraphs of Article 4. Accordingly, Article 4(4) holds that 'Member States shall ensure that support for electricity from renewable sources is granted in an open, transparent, competitive, non-discriminatory and cost-effective manner'. This provision introduces certain procedural requirements that are not further defined. But they hint at tendering procedures, as confirmed by Article 4(5), (6) and (8), which explicitly refers to such procedures. ${ }^{34}$ Thus, price RESSS are coupled with elements that originate from quantity instruments, if not even linked with a certain quantity RESSS, namely auctions. Although RED II does not include auctions in the indicative list of support schemes of Article 2(5), it is well-established in literature that auctions constitute a distinct quantity RESSS and not just an allocation procedure. ${ }^{35}$ 
Nevertheless, Article 4(4) should not be interpreted as always requiring auctioning. Any procedure that ensures support is granted in an open, transparent, competitive, non-discriminatory and cost-effective manner is in accordance with the provision at hand. For instance, the Cypriot and the Greek net metering regimes have launched an open call for interested persons to get involved in them, without entailing a tendering procedure. Still, they comply with the foregoing requirements and, hence, are in line with RED II. Besides, the Article 4(4) procedural principles are not absolute, but small-scale installations and demonstration projects may be exempted.

In summary, Article 4 does not require Member States to turn to certain types of RESSS, but it does show a preference for quantity instruments. Indeed, Member States are generally restricted to not enact feed-in tariffs; and when they opt for other price support schemes they shall in principle integrate elements that pertain to quantity RESSS into their design. This confirms the stance that had been adopted already with soft law. Still, as the next part will demonstrate, price RESSS retain their pre-eminence in the field of self-consumption.

\section{PRICE SUPPORT SCHEMES AND SELF-CONSUMPTION}

The Clean Energy Package is not merely linked with the promotion of renewable energy sources, but also with the empowerment of energy consumers, in an effort to make them active actors in the energy market and to make them take ownership of the low-carbon transition. ${ }^{36}$ In this regard, it is no surprise that RED II acknowledges the rise of selfconsumption of energy from renewable sources and enshrines certain rights for self-consumers and for energy communities that will allow them to generate, consume, store, and sell electricity without facing disproportionate burdens. ${ }^{37}$ More specifically, Article 21(2) requires Member States to ensure that self-consumers are inter alia entitled to 'receive remuneration, including, where applicable, through support schemes, for the selfgenerated renewable electricity that they feed into the grid, which reflects the market value of that electricity and which may take into account its long-term value to the grid, the environment and society'. As for energy communities, RED II did not introduce an explicit right to remuneration; still, according to Article 22(2), they are entitled to 'produce, consume, store and sell renewable energy'.

Given the above, Member States are expected to enact RESSS that particularly fit self-consumption, like net metering. Certain Member 
States have already enacted net metering regimes that grant the selfconsumer a remuneration for the energy that they generate on their own and they subsequently sell to the grid. Of course, such regimes shall be in conformity with Article 4 of RED II. They shall not cause unnecessary distortions of the electricity market and they shall be market-based and market-responsive.

It is doubtful whether net metering can be in conformity with these principles, although it can serve the requirements of Articles 21 and 22 of RED II. This is because under a typical net metering scheme selfgenerated energy is overpriced. Energy suppliers are required to purchase it at the retail price, while they could differently trade energy bought from wholesale producers at a lower price. ${ }^{38}$

In spite of the foregoing characteristics, and in accordance with the Article 4(3) exemption, net metering is not proscribed for small-scale installations or demonstration projects. Since net metering particularly addresses self-consumers, it is normally small-scale installations, like households, that will be covered by such schemes. But this exemption cannot be invoked if RESSS unnecessarily distort the electricity market. And this might actually happen if net metering excessively expands and too many installations engage in it. Then, as the 'death spiral' theory suggests, suppliers will be finding it too costly to remunerate all these self-consumers, while at the same time their clientele will be diminishing. Such a construct is not affordable and threatens the stability of the whole electricity system. ${ }^{39}$

But net metering can be designed in a market-based and marketresponsive way. This is the net billing variation, in which the price of energy outputs is set lower than the price of inputs. ${ }^{40}$ In other words, energy sold to the grid is valued at a lower price compared to energy bought from the grid. Thus, net billing encourages actual self-consumption, which also entails less use of the grid and diminishes grid congestion. Moreover, thanks to the development of smart meters that provide real-time price information, any transaction between self-consumers and suppliers can be conducted on the basis of the actual energy prices and not of fixed prices. This renders the system even more market-based and market-responsive.

Given the above, net billing is compatible with Articles 4, 21 and 22 of RED II. The Commission has also argued that net metering is effective to 'jump-start' self-generation and self-consumption, but in the next stages net billing schemes should be preferred. ${ }^{41}$ Certain Member States, like Cyprus, Denmark, Finland, Italy or Portugal have already resorted to net billing. Interestingly, Cyprus applies net billing to larger actors that are par excellence in a position to significantly affect the system, while net metering is limited to households. Moreover, there is a limit for the 
aggregated installed capacity that can benefit from net billing, which prevents a potential overexpansion of the regime. ${ }^{42}$

\section{CONCLUSION}

While Member States have been typically using price RESSS, the Commission has been sceptical towards them and has been supporting the enactment of quantity instruments. The criticism that price RESSS are not market-based, but market-distorting has been strengthened since the early 2010s, when numerous ambitious price support schemes collapsed.

Recently, RED II introduced a body of secondary supranational renewable energy support provisions. Amongst them, Article 4 governs the selection and design of RESSS. This article does not demand certain types of RESSS to be used, but it intervenes in a principle-based manner. Accordingly, Member States are required to enact market-based and market-responsive RESSS that do not unnecessarily distort electricity markets. This mostly impacts on price RESSS. Indeed, according to Article 4 , in principle only feed-in premiums comply with the foregoing rules, and only if coupled with tendering procedures. On the other hand, it seems to be the default position that quantity instruments comply with the law and do not cause problems to the functioning of energy markets.

Nevertheless, the above do not signal the end of price RESSS. On the contrary, price instruments still have a role to play, as they are more attractive for investors and they can thus boost investments in renewable energy technologies, especially the most costly or the experimental ones. Besides, RED II allows the enactment of feed-in premiums and includes exemptions that leave significant room for other price RESSS, like feed-in tariffs. Moreover, net metering is a price RESSS that particularly promotes self-consumption, which is a policy objective emphatically acknowledged by RED II.

Second, and most importantly, RED II might trigger the inspiration of the authorities so that they design and enact more market-based and market-responsive price RESSS or even hybrid instruments that combine elements from both price and quantity RESSS. This is, for example, the abovementioned case of feed-in premiums coupled with auctions, or the case of net billing and smart metering coupled with maximum capacity limits.

Of course, the fact that the compatibility of support schemes with RED II depends on indeterminate legal concepts, to wit the abovementioned principles, poses an interesting interpretative challenge. Furthermore, it is hard to predict what the consequences will be if RESSS are found not to be 
in accordance with the law. This will be much dependent on the eagerness of the Commission to exercise its powers and issue recommendations or even start infringement procedures against Member States. It is noted that the Commission has not taken any action against Member States who have not been conforming with the requirements set down by the previous Renewable Energy Directive 2009/28/EC. But the Commission is now armed with more powers, conferred on it by the Energy Governance Regulation. ${ }^{43}$ Moreover, given the climate change threat, the energy transition imperative and the policy priorities set, one can only be optimistic that more effective action will be taken.

\section{NOTES}

* Theodoros G. Iliopoulos is doctoral researcher in energy and environmental law at Hasselt University: theodoros.iliopoulos@uhasselt.be.

1. See Commission, 'United in delivering the Energy Union and Climate Action - Setting the foundations for a successful clean energy transition', COM(2019) 285 final.

2. Directive (EU) 2018/2001 of the European Parliament and of the Council of 11 December 2018 on the promotion of the use of energy from renewable sources [2018] OJ L328/82.

3. Ibid., Article 3(1).

4. Directive 2009/28/EC of the European Parliament and of the Council of 23 April 2009 on the promotion of the use of energy from renewable sources and amending and subsequently repealing Directives 2001/77/EC and 2003/30/EC [2009] OJ L140/16.

5. Directive 2018/2001 (n 2), Article 3(4). See also Article 32(4) of Regulation (EU) 2018/1999 of the European Parliament and of the Council of 11 December 2018 on the Governance of the Energy Union and Climate Action, amending Regulations (EC) No $663 / 2009$ and (EC) No 715/2009 of the European Parliament and of the Council, Directives 94/22/EC, 98/70/EC, 2009/31/EC, 2009/73/EC, 2010/31/EU, 2012/27/EU and 2013/30/EU of the European Parliament and of the Council, Council Directives 2009/119/EC and (EU) 2015/652 and repealing Regulation (EU) No 525/2013 of the European Parliament and of the Council [2018] OJ L328/1.

6. Regulation 2018/1999 (n 5), Articles 3-5, 9 and 29-34.

7. See Pablo del Río and Pere Mir-Artigues, 'Combinations of Support Instruments for Renewable Energy in Europe: A Review’ (2014) 40 Renewable and Sustainable Energy Reviews 287.

8. Many Member States, like Belgium, France, Greece, Ireland or the Netherlands have enacted such tax incentives.

9. del Río and Mir-Artigues (n 7). See also Anna Bergek, Ingrid Mignon and Gunnel Sundberg, 'Who Invests in Renewable Electricity Production? Empirical Evidence and Suggestions for Further Research' (2013) 56 Energy Policy 568, 574.

10. Reinhard Hass et al., 'A Historical Review of Promotion Strategies for Electricity from Renewable Energy Sources in EU Countries' (2011) 15 Renewable and Sustainable Energy Reviews 1003; Philippe Menanteau, Dominique Finon and Marie-Laure Lamy, 'Prices Versus Quantities: Choosing Policies for Promoting the Development of Renewable Energy' [2003] Energy Policy 799.

11. Sharon B. Jacobs, 'The Energy Prosumer' [2017] Ecology Law Quarterly 519.

12. Commission, 'European Commission Guidance for the design of renewables support schemes' SWD(2013) 439 final, ch 3.1.1.

13. Council of European Energy Regulators, 'Status Review of Renewable Support 
Schemes in Europe for 2016 and 2017' (Public Report C18-SD-63-03, 2018), ch 2; Commission (n 12), p.24. See also Mario Ragwitz et al., 'Review report on support schemes for renewable electricity and heating in Europe' (D8 Report, The RE-Shaping project, 2011), ch 4.

14. Cameron Hepburn, 'Carbon Taxes, Emissions Trading and Hybrid Systems' in Cameron Hepburn and Dieter Helm (eds), The Economics and Politics of Climate Change (Oxford University Press 2009); Dominique Finon and Yannick Perez, 'The Social Efficiency of Instruments of Promotion of Renewable Energies: A TransactionCost Perspective' (2007) 62 Ecological Economics 77; Lori Snyder Bennear and Robert N. Stavins, 'Second-Best Theory and the Use of Multiple Policy Instrument' (2007) 37 Environmental and Resource Economics 111; Martin L. Weitzman, 'Prices vs. Quantities' [1974] The Review of Economic Studies 477.

15. Ibid.

16. Angus Johnston and Guy Block, EU Energy Law (Oxford University Press 2012); James Prest, 'The Future of Feed-In Tariffs: Capacity Caps, Scheme Closures and Looming Grid Parity' [2012] Renewable Energy Law and Policy Review 25. See also Theodoros Iliopoulos, 'Renewable Energy Regulation: Feed-in Tariff Schemes under Recession Conditions?' [2016] European Networks Law and Regulation 110.

17. Sofia-Natalia Boemi and Agis M. Papadopoulos, 'Times of Recession: Three Different Renewable Energy Stories from the Mediterranean Region' in Evanthie Michalena and Jeremy Maxwell Hills (eds), Renewable Energy Governance (Springer 2013).

18. Volkmar Lauber and Moritz Buschmann, 'Germany: Challenges of a Full Transition to Renewable Energy' in Michalena and Hills (n 17).

19. Council of European Energy Regulators (n 13), ch 2.

20. Commission (n 12), ch 3.1.7.

21. David Jacobs, 'Designing Financing Mechanisms for Electricity from Renewable Energy Sources: The Role of the European Commission as an Agenda Shaper' in Jale Tosun, Sophie Biesenbender and Kai Schulze (eds), Energy Policy Making in the EU (Springer 2015).

22. Fabio Antoniou and Nikos Tsakiris, 'On the Informational Superiority of Quantities Over Prices in the Presence of an Externality' (2016) 65 Environmental and Resource Economics 227; Michael Hoel, 'Emission Taxes Versus Other Environmental Policies' [1998] Scandinavian Journal of Economics 79; Robert N. Stavins, 'Correlated Uncertainty and Policy Instrument Choice' (1996) 30 Journal of Environmental Economics and Management 218; Maureen L. Cropper and Wallace E. Oates, 'Environmental Economics: A Survey' [1992] Journal of Economic Literature 675; Marc J. Roberts and Michael Spence, 'Effluent Charges and Licenses Under Certainty' (1976) 5 Journal of Public Economics 193; Weitzman (n 14).

23. Commission, 'A Framework Strategy for a Resilient Energy Union with a ForwardLooking Climate Change Policy' COM(2015) 80 final. See also Finon and Perez (n 14).

24. Case C-573/12 Alands Vindkraft [2014] (published in the electronic Reports of Cases).

25. Jacobs (n 21). See also Theodoros Iliopoulos, 'Dilemmas on the Way to a New Renewable Energy Directive' [2018] European Energy and Environmental Law Review 210 .

26. Guidelines on State aid for environmental protection and energy 2014-2020 [2014] OJ C200/1; Commission (n 12).

27. Consolidated version of the Treaty on the Functioning of the European Union [2016] OJ C202/47.

28. Case C-405/16 P Germany v Commission [2019] (published in the electronic Reports of Cases); Case C-262/12 Vent De Colère and Others [2013] (published in the electronic Reports of Cases); Case C-206/06 Essent Netwerk Noord and Others [2008] ECR I-5497; Case C-379/98 PreussenElektra [2001] ECR I-2099.

29. Directive 2018/2001 (n 2). Apart from Article 4, Article 5 nudges Member States to enact cross-border RESSS; Article 6 sets down certain requirements ensuring the stability of the support framework; Article 13 encourages the enactment of joint RESSS between 
Member States; and Articles 21 and 22 relate to the promotion of self-consumption of energy from renewable sources and of renewable energy communities respectively.

30. It is important to note that Article 4 only establishes principles and rules applicable to RESSS for electricity. RED II does not restrict Member States when they enact RESSS for cooling and heating or for transport. But the categorisation is not particularly clear; for instance, the use of electric cars can be grouped in both electricity and transport.

31. See for instance Case T-57/11, Castelnou Energía v Commission [2014] (published in the electronic Reports of Cases); Case C-403/10 P Mediaset v Commission [2011] ECR I-117.

32. See Judgment No 83/2017, 22 June 2017, Constitutional Court of Belgium.

33. Directive 2018/2001 (n 2), recital 17.

34. Paragraph 5 establishes the principle for technology-neutral tendering procedures and sets down certain grounds for exception; paragraph 6 sets down rules that ensure a high project realisation rate; last, paragraph 8 relates to a monitoring and evaluating procedure that will be analysing the performance and effects of support granted after tendering procedures.

35. See Jacobs (n 21), pp. 115-116; Hass et al. (n 10).

36. Saskia Lavrijssen, 'Power to the Energy Consumers' [2017] European Energy and Environmental Law Review 172.

37. Directive 2018/2001 (n 2), Articles 21 and 22; recitals 66-69.

See also Articles 15 and 16 of Directive (EU) 2019/944 of the European Parliament and of the Council of 5 June 2019 on common rules for the internal market for electricity and amending Directive 2012/27/EU [2019] OJ L 168/125.

38. David Raskin, 'Getting Distributed Generation Right: A Response to "Does Distributive Competition Mean a Death Spiral for Electric Utilities?"' [2014] Energy Law Journal 263; Elisabeth Graffy and Steven Kihm, 'Does Distributive Competition Mean a Death Spiral for Electric Utilities?' [2014] Energy Law Journal 1.

39. Ibid.

40. Rodolfo Dufo-López and José L. Bernal-Agustín, 'A Comparative Assessment of Net Metering and Net Billing Policies' (2015) 84 Energy 684; Andreas Poullikkas, George Kourtis and Ioannis Hadjipaschalis, 'A Review of Net Metering Mechanisms for Electricity Renewable Energy Sources' (2013) 6 International Journal of Energy Environment 975.

41. Commission, 'Best practices on Renewable Energy Self-consumption' SWD(2015) 141 final, p. 10.

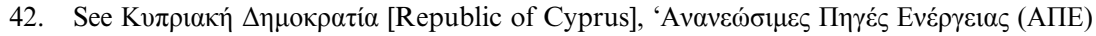

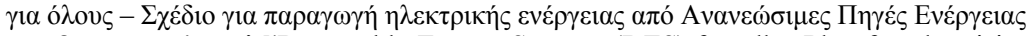

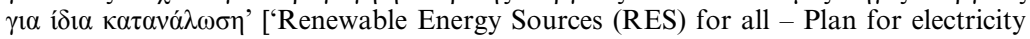
production from Renewable Energy Sources for self-consumption'], March 2019.

43. Regulation 2018/1999 (n 5). 